\title{
Rain in the Basilica: Protecting Goa's Bom Jesus from the Ravages of Climate Change
}

\author{
Vishvesh Prabhakar Kandolkar \\ (Dhttps://orcid.org/0000-0001-5150-9024
}

Goa College of Architecture (Goa University), India

\begin{abstract}
Over the last century, monsoons in Goa have become more intense, with an increase of over $68 \%$ in rainfall (Goa State Biodiversity Board, 2019, p. 42). Such effects of climate change are devastating to architectural heritage, especially those structures built using materials like laterite, a weaker stone, vulnerable to rapid deterioration when it is left exposed. This is the precise problem concerning the Basilica of Bom Jesus, a sixteenth century building that is still in use. The monument which houses the relics of St. Francis Xavier is one of the most important cultural icons of Goa, as evidenced by its ongoing use and also its iconic representation in visual culture. While research may be available regarding the effects of climate change and architecture in the tropics generally, little pertains to the specificities of IndoPortuguese architecture and especially heritage buildings. My article seeks to make an intervention in this regard, focusing on the effects of climate change with regard to the conservation of Bom Jesus. Considering the adverse effects of climate change on built heritage, architectural conservation in Goa cannot be merely about preserving cosmetic appearances, but rather must involve safeguarding monuments against major structural damage.
\end{abstract}

Keywords: Goa, Climate Change, Monsoon, Architectural Conservation, Basilica of Bom Jesus, St. Francis Xavier, Tropics, Climate Imaginary

eTropic: electronic journal of studies in the tropics publishes new research from arts, humanities, social sciences and allied fields on the variety and interrelatedness of nature, culture, and society in the tropics. Published by James Cook University, a leading research institution on critical issues facing the world's Tropics. Free open access, Scopus Listed, Scimago Q1. Indexed in: Google Scholar, DOAJ, Crossref, Ulrich's, SHERPA/RoMEO, Pandora. ISSN 1448-2940. Creative Commons CC BY 4.0 free to download, save and reproduce. To cite, include: Author(s), Title of Paper, Editors (Eds.) Special Issue Title (Special Issue) eTropic, volume, issue, year, pages and DOI: http://dx.doi.org/10.25120/etropic.20.2.2021.3814 
eTropic 20.2 (2021) Special Issue: Tropical Imaginaries and Climate Crisis

$\mathrm{T}$

he Basilica of Bom Jesus, a sixteenth century religious building that is still in use, is located in Goa, a tiny coastal state in South Asia bordered by the Arabian Sea. From the time when the relics of St. Francis Xavier (1506-1552) were entombed in Bom Jesus in 1624 (Fonseca, 1878, p. 286), the building became an important pilgrimage site. Goa was, and continues to be, the centre of the Christian world in Asia because of the relics of the famous Jesuit saint. The feast of the saint, celebrated each year on December 3, draws huge gatherings, as does the exposition of his relics that became a decadal event from the mid-nineteenth century onwards.

Although Xavier died in China, it was Goa - capital of the Portuguese Empire in Asia - that received his mortal remains in $1554,{ }^{1}$ which were believed to be miraculously preserved from blemish (Gupta, 2014, p. 27). St. Francis Xavier is the patron saint of Goa, and Goans "share a strong belief that the state is protected from all calamities due to the presence of the saint's relics" in Old Goa (D'Cruz, 2019). That locals have adopted him as their own is evidenced by the title given to him in Concanim, ${ }^{2}$ Goyencho Saib translating as "Lord of Goa."

Consecrated in 1605 by the Jesuits, the Basilica of Bom Jesus stood intact for more than four centuries, but then in April 2020, a gaping hole appeared in its roof. This caused damage to the church that year, as unseasonal rains soaked the walls and wood of the structure (Team Herald, 2020, para. 4). The current rector of the Basilica, Fr. Patricio Fernandes, raised the alarm, accusing the Archaeological Survey of India (ASI) - the agency responsible for the protection and maintenance of the monument - of "utter neglect...leading to the deterioration of the Basilica and the Shrine of 'Goyencho Saib,' St. Francis Xavier" (NT Desk, 2020, para 1). Apart from being the tomb of the saint, Bom Jesus - along with churches and convents of Old Goa - was declared a World Heritage Site in 1986 (UNESCO, 1986). Given its long historical and religious importance, and over twenty years of world heritage significance, the question remains why the ASI has been compromising the safety of the building.

This article sets out to address this question. Focusing on the effects of climate change on Bom Jesus, the article necessarily explores the cultural, historical, colonial, political, architectural, and tropical monsoonal factors affecting the Basilica's current deterioration and its future conservation.

\footnotetext{
1 The remains first went to the Portuguese colony of Malacca on Peninsula Malaysia and two years later were sent to Goa where they were stored at St. Paul's College in Old Goa until they found their final resting place in the Basilica.

${ }^{2}$ Although written in many scripts including the Roman (or Romi) script, only Kōńkaṇi written in the Devanagari script became the official language of Goa in 1987. This official designation undermines the popular use of the language in the Romi script (especially by the Catholic community); even during the late Portuguese period in Goa this version of the language - Concanim - was in extensive use, including in local newspapers.
} 


\section{Climate Change and South Asia}

Over the last century, monsoons in Goa have become more intense, with an increase of over $68 \%$ in rainfall (Goa State Biodiversity Board, 2019, p. 42). Such effects of climate change are devastating to architectural heritage, especially those structures built using weaker materials like laterite, a stone which is vulnerable to deterioration particularly when it is left exposed (Patil \& Kasthurba, 2021, p. 1657). While research is available regarding the effects of climate change on the region of Goa (Evan et al., 2011; Murakami et al., 2017; Prathipati et al., 2019; Shetty, 2021; Wang et al., 2012), little of it pertains to the specificities of the heritage of Goa's Indo-Portuguese architecture. Considering the adverse effects of climate change on built heritage, architectural conservation in Goa cannot be merely about maintaining cosmetic appearances, but rather protecting monuments against major structural damage.

Figure 1. Basilica of Bom Jesus

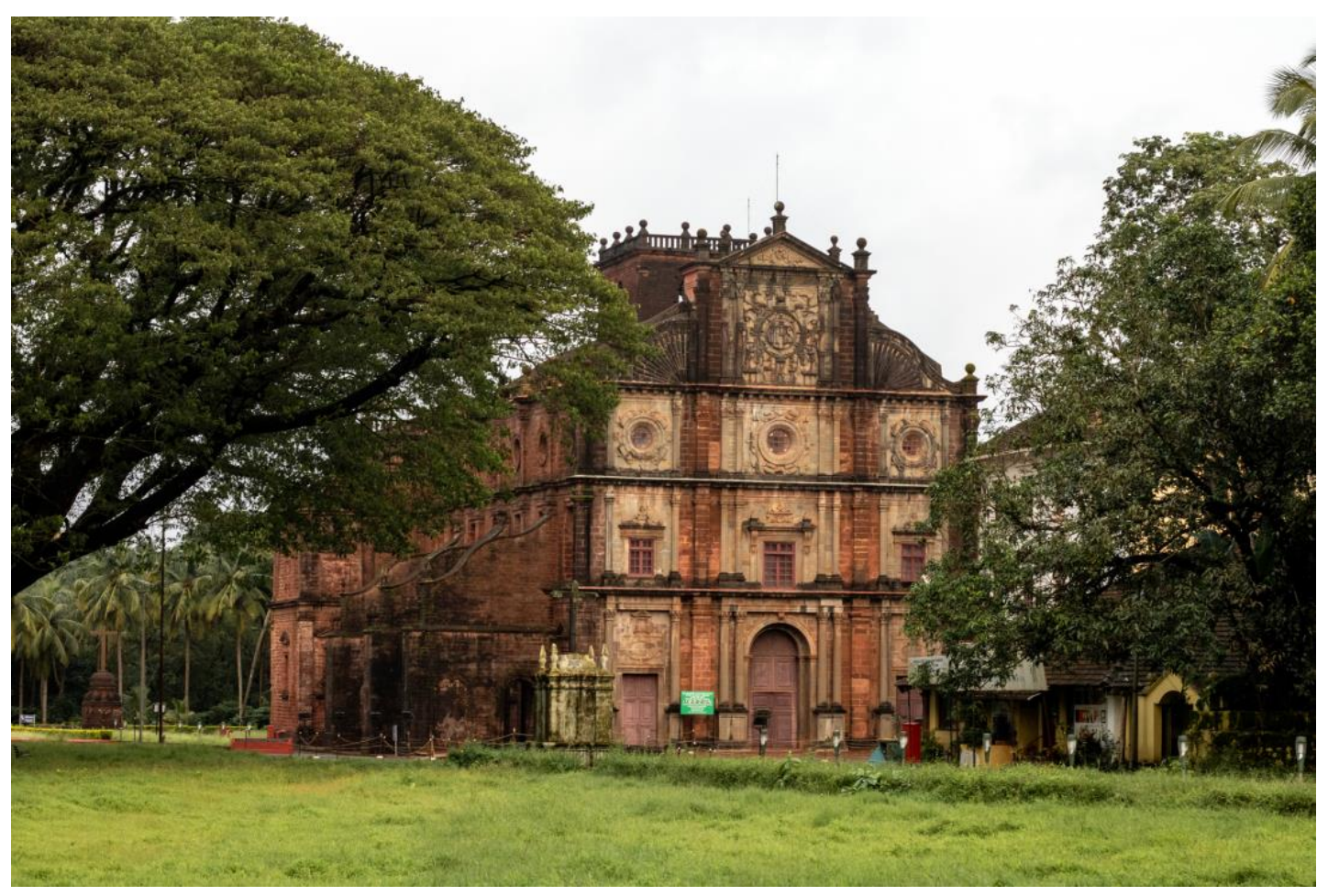

The Basilica continues to be lashed by increasingly incessant and extremely heavy monsoonal rains, affecting the conservation of the exposed laterite walls of the church. (Author's photograph, August 2021).

Facing the brunt of increasingly severe rainfall and stronger tropical storms every year, the threat to Goa's built heritage serves as yet another example of how climate change has affected monsoonal South Asia. The ruination of Indo-Portuguese architectural heritage, however, is seldom seen as a part of the imagery that informs the climate 
eTropic 20.2 (2021) Special Issue: Tropical Imaginaries and Climate Crisis

change discourse. According to Saffron O'Neill and Nicholas Smith, "[w]hile a diversity of climate change imagery exists, particular types of climate imagery appear to have gained dominance, promoting particular ways of knowing about climate change (and marginalizing others)" (2014, p. 73). O'Neill and Smith thus imply that the usual visual tropes of climate change that dominate global discourse have been biased: images concentrate on impending impacts for temperate latitudes, as evidenced by the recurrent and widely circulated images of melting polar ice sheets; and they are also biased towards large catastrophic events in nature.

Any focus on the Global North fails to account for how ice sheets melting in Greenland and Antarctica will also have devastating effects on the tropics, as "complexities of oceanic systems indicate that sea level rise will not occur evenly around the globe" and "will more strongly impact sea level rise in the Tropics" (Lundberg, 2020, pp. 9192). In the Asia-Pacific region, seas are predicted to be "further impacted by the atmospheric systems of the Indian Ocean Dipole (IOD) and the EI Niño-Southern Oscillation (ENSO)", causing an "increase in frequencies and intensities of oceanicatmospheric phenomena," especially "cyclones" (Azzali et al. 2020, pp.6-7). That is, although the tropics are doubly affected by climate change - sea level rise in addition to locally produced effects such as stronger tropical storms - the global discourse on climate change continues be dominated by visuals in reference to the potential demise of the Global North.

Furthermore, the emphasis on environmental devastation, as important as it is, tends to veil the potential demise of material culture - including architectural elements that have world heritage value. The rain entering Goa's iconic Basilica in April 2020 is a symptom of a larger issue - it points to climate change outside which has breached the boundaries of the monument. Because monuments like Bom Jesus do not stand independently of their environments, the imagery of climate change is incomplete without considering its effect on architecture.

\section{Colonial Politics and Architecture}

Today, a generation of Goans has grown accustomed to seeing the Basilica's exposed laterite walls, but this is not the way the building was designed, nor indeed the way it looked until about 70 years ago (Kandolkar, 2020b, para. 8). It was the former Director of the Department of Monuments in Portugal - architect-restorer, Baltazar da Silva Castro - appointed by the colonial government to Goa, who in the 1950s brought about the dramatic transformation of the external appearance of the Basilica by having the render $^{3}$ removed and leaving the underlying laterite stone exposed (dos Santos,

\footnotetext{
${ }^{3}$ When mortar is used to finish external walls, it is called render; when used indoors, it is called plaster. In this article, the mortar used on the external surface of buildings shall be referred to as render. Mortar is typically
} 
eTropic 20.2 (2021) Special Issue: Tropical Imaginaries and Climate Crisis

2017). Essentially, the politically motivated restoration - commissioned at a time when decolonial efforts were ramping up in Asia and Africa - was meant to make an old building look even older.

Figure 2. Tomb of St. Francis Xavier in Basilica Bom Jesus

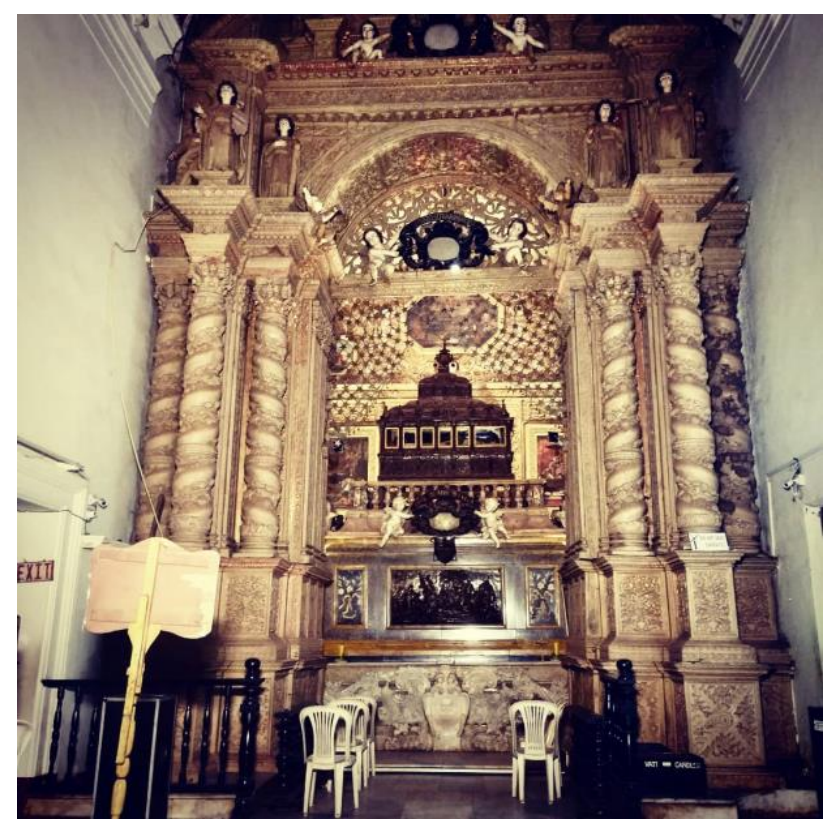

The body of the saint is kept in a silver casket above a marble pedestal. The chapel dedicated to the saint is in the alcove of the church's right-hand side transept. Fr. Patricio mentions that the wall of the chapel was damaged due to the rains entering the Basilica in April 2020. (Photo: Lester Silveira 2020).

During the 1952 exposition of the saint's relics, thousands of people from across the world gathered in Old Goa (Gupta, 2014, p. 204). Through restoring monuments such as Bom Jesus - historical buildings which showed a cross-fertilisation between European elements and regional ones - the twentieth century Portuguese colonial state was projecting that Goa was unlike its neighbouring Indian region. da Silva Castro undertook restoration of monuments in Old Goa, so that architecture could serve as evidence of Portugal's long history in the region. In the process, the removal of the Basilica's render to make it appear older endangered the church, lashed as it is by heavy Goan monsoonal rains annually.

The outer layers of the Basilica that consist of external walls and rooves are subjected to maximum wear and tear because they are exposed to the elements of nature, be it rains, temperature fluctuations, or latent pollution in air. Even walls made of hard stones are not spared. Contrary to common perception, quarried stones used in

described as a mixture of aggregates (like sand), binder (like lime used until the nineteenth century or mostly Portland cement in the twentieth century), and water. Mixing of the binder with water produces a paste, which must coat loose grains of aggregate to yield a cohesive material after hardening (Nogueira et al., 2018, p. 193). 
building are not immune to weathering. Rather, the "exposure of stone to aggressive environmental conditions" leads to their rapid deterioration (Smith et al., 2008, p. 441). Therefore, experts recommend that the walls are coated with renders because they operate as a sacrificial layer between stones and the environment (Nogueira et al., 2018 , p. 196). Having been stripped of its external protective layer in the 1950s, the exposed laterite stones of the Basilica were also directly exposed to the harsh tropical climatic of Goa.

The 1950s was not the first restoration work undertaken on the Basilica. In fact, in the 1860 s, a major restoration of the church involved the complete overhaul of the roof of the building, while three major buttress walls were added to support the northern wall of the church (de Albuquerque, 1890, p. 13). Such timely action of safeguarding the structure, ensured that the monument has enjoyed a long life.

Figure 3. 1890 Photograph of the Basilica of Bom Jesus

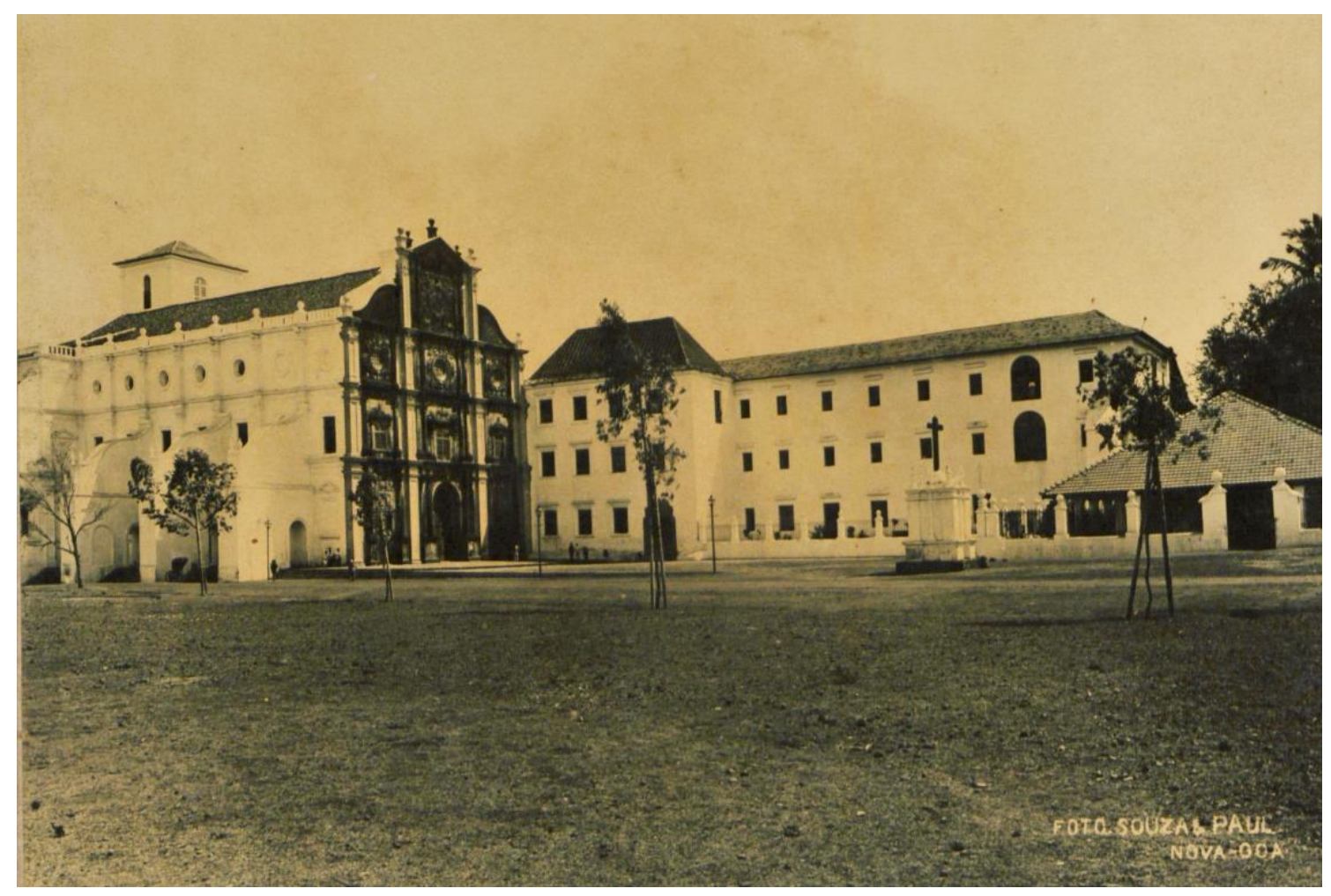

Original lime-rendered and whitewashed Basilica of Bom Jesus in 1890, photographed by Souza and Paul. The current look of the Basilica is the result of restoration carried out by the Portuguese architectrestorer Baltazar da Silva Castro in the 1950s. Source: Souza \& Paul Collection, Central Library, Goa.

In contrast to modifications to the Basilica in the 1860s, the 1950s changes were only surface-level restorations. This was in keeping with former Portuguese Prime Minister, António de Oliveira de Salazar's nationalistic ideology in which monuments were 
medievalised, that is falsely 'restored' to look ancient, in order to proclaim the antiquity of the Portuguese Empire. Dos Santos adds that many such ideologically-motivated restorations were initially undertaken in Salazar-ruled Portugal during the 1940s to reinforce the nationalistic agenda under the dictatorial government of the Estado Novo (dos Santos, 2017, p. 247).

Furthermore, due to the decline of Portuguese imperial power in the twentieth century, the state resorted to restoring monuments from the medieval and early modern period to give the impression of the long lineage of the Portuguese 'nation'. India's independence from the British Empire in 1947, meant that the newly-formed country was agitating for the decolonization of Goa. However, the colonial Prime Minister Oliveira de Salazar was unwilling to part with the territory, because he considered that "Goa [was] the transplantation of the West onto Eastern lands, the expression of Portugal in India" (1956, p. 420). And in order to further showcase Goa's Europeanised culture, the colonial state organised the grand exposition of St. Francis Xavier's relics in 1952, which marked the 400 years of the saint's death. In the moment of decoloniality, the 400-year-old relics of St. Francis Xavier and architecture of the sixteenth-century church and convents in Old Goa were used to highlight the cultural difference of Goa from India, and the longevity of the Portuguese empire in Asia. In removing the 'skin' of buildings, such as Bom Jesus in Old Goa, da Silva Castro was able to transform architecture into relics of Portugal's colonial past. Along with the relic of the saint, historical buildings like Bom Jesus could also serve as evidence of the longevity of Portuguese presence in Goa. That these kinds of restoration were earlier undertaken by da Silva Castro in Portugal under Salazar's dictate, indicates an imperial continuity between metropole and colony. What may seem to have been a minor restoration in the centuries-long history of Bom Jesus was the product of particular design underscored by political intent.

It is remarkable that the exposed laterite walls of the Basilica have withstood the onslaught of the Goan monsoon since the 1950s. The same fate was not accorded to the Arch of the Viceroy's - another monument in Old Goa whose render was also removed on the recommendation of restorer da Silva Castro during the same period. This monument crumbled during heavy monsoon rains that followed its 'restoration' in 1953 and the Viceroy's Arch visible today is a reconstructed version of the original. In fact, the colonial administration became aware of the problems of the Basilica without its protective render - and thus its exposure to the elements - and were in the process of rectifying their mistake in the 1960s (dos Santos, 2016).

However, this was the end of Portugal's colonial reign. After Goa was integrated with India in 1961, the ASI took charge of safeguarding the Basilica and other monuments from 1968 onwards (ASI Goa Circle, n.d.). Arguably, the building continues to remain without its render because this was its condition when the ASI took over the 
eTropic 20.2 (2021) Special Issue: Tropical Imaginaries and Climate Crisis

responsibility of its protection. The ASI misinterprets the exposed-laterite appearance of the Basilica as belonging to the 'Portuguese' colonial period, even though the monument was rendered and whitewashed for most of its life (see Figure 3). Such simplistic categorisation of buildings based on a political timeline is problematic because the architecture of Bom Jesus did not remain the same even during the colonial period. Maintaining the exposed appearance of the Bom Jesus shows that the ASI fails to grasp the complexity of the architectural and restoration history of the monument, especially its transformation during the dictatorial period of Estado Novo.

\section{Monsoons and Stones}

Prominent environmentalist and Nobel Prize Laurette Rajendra Kumar Pachauri has warned that the coastal location of Goa makes it highly vulnerable to the effects of climate change (TNN, 2014). For example, the rise in temperatures of oceans, especially over the Arabian Sea, has increased the frequency of tropical storms along the western coast of India. Apart from the frequency, experts predict that climate change is going to intensify tropical pre-monsoon cyclones over the Arabian Sea (Evan et al., 2011, p. 94; Wang et al., 2012, p. E1). Not surprisingly, this year, along with the western coast of India, Goa was lashed by the strongest cyclone to ever hit the region (Yeung \& Mitra, 2021). Cyclone Tauktae "was an unusually strong cyclone in the Arabian Sea, resulting in widespread disruption" (Vallangi, 2021). It is not only increased intensity of monsoons but also cyclones that adversely affect heritage sites in Goa. The increased precipitation and recurrence of strong cyclones means the region's monuments such as Bom Jesus are not fully equipped to deal with dramatic climate change.

Over the years, areas around Bom Jesus and other the UNESCO World Heritage Sites in Old Goa are undergoing rapid urbanisation, which in turn is threatening the conservation of these monuments in multiple ways. As Amitav Ghosh notes, "Goa's ecology...is experiencing huge man-made impacts. It has become extremely builtover and greatly urbanised, with massive road building works" (2021, para. 1). It is an irony that Ghosh makes these comments about Goa, because the infrastructure in the state is being developed to accommodate non-Goan elite settlers like him. One example of massive road construction in Goa is the major national highway, which cuts across the historic city of Old Goa. During the 2020 monsoons, this led to heavy flooding of Old Goa, as water flowed from the deforested areas along the newly built highway into the low-lying parts of the city where the Basilica is located (TNN, 2021b). Flooding and improper drainage of rainwater also leads to the rise in the water table around the Basilica. The rising water table is detrimental to heritage structures which are built using porous laterite, as it causes salt ingress from the ground through capillary action (Kasthurba et al., 2006, p. 1327). To make matters worse, the 
eTropic 20.2 (2021) Special Issue: Tropical Imaginaries and Climate Crisis

Basilica's plinth is much lower than the surrounding roads, making the monument vulnerable to flooding (Velho, 2021). In short, climate change and rapid uncontrolled urbanisation in and around Old Goa is threatening the safety of Bom Jesus.

While the increase in the mean annual rainfall by $68 \%$ over the last century is detrimental to heritage sites, it is the increased frequency of extreme rainfall events that leads to wear and tear of monuments. As a result of heavy rains, many heritage monuments in Goa have collapsed in the last few years (TNN, 2020). The effects of climate change are detrimental not just to buildings with exposed laterite, but are equally damaging to monuments constructed with stronger, much denser, stones. For example, the World Heritage structures of Angkor Wat in Cambodia, which have exposed sandstone, are also undergoing weathering due to the tropical conditions, including strong sunlight and plenty of rainfall (Liu et al., 2020, p. 11). While intensity of rainfall causes weathering of exposed stones, increased acidity in rainfall, which is triggered by high levels of atmospheric pollution, are even more harmful (Smith et al., 2008 , p. 441). The pollution from heavy vehicles plying the six-lane highway and rapid urbanization of areas surrounding the Basilica, means its exposed-laterite stones are adversely affected.

The catastrophe for Bom Jesus is the human-made disaster of climate change combined with another (modern) human-made misadventure of removing the protective render from the laterite stone walls. Common to popular belief in Goa is that laterite stones can withstand harsh environmental conditions. As Smith, GomezHeras, \& McCabe advise: "The assumption that placing stone in a building immunizes it from the natural processes of weathering is partly the consequence of a lack of public awareness of weathering processes and what controls them" (2008, p. 441).

Hot and humid conditions in the tropics, be it in Goa or Cambodia, lead to quick growth of natural flora, plants and microorganisms on exposed stone surfaces causing rapid deterioration of the material. Protection and preservation of the architecture of the Angkor World Heritage Sites, for example, requires persistent effort, as sandstone has been undergoing "deterioration from the tropical climate and invasion by plants, and colonization by different microflora" (Liu et al., 2020, p. 10). Considering that the porous and weaker laterite stone is even more vulnerable to the increasingly harsh climate of Goa, would it not be better for the ASI to restore the protective sacrificial layer of lime-based render?

Laterite was abundantly available in Goa and was used not only in the Basilica, but elsewhere, and even before Portuguese colonisation. However, the stone needs to be protected to withstand the harsh climate of the region. Goa is a part of Konkan and Malabar coast of India, where monuments with laterite stones are often damaged due to "lashing rain, wetting and drying cycles and thermal changes," which cause loss of 
cohesion of minerals, resulting in granular disintegration of laterite stone surfaces (Kasthurba et al., 2006, p. 1325). Laboratory testing conducted by Sutapa Das shows that "[i]n spite of high content of strength-giving iron oxide, Goan laterite is weak in compression and flexure even compared to standard brick" (Das, 2008). Once again, this observation is contrary to the common perception that stone blocks are generally stronger than bricks. Therefore, if ordinary brick buildings require render, then surely the laterite ones should also follow suit because they are more vulnerable. The porosity of the laterite stone is what effects its load-bearing capacity, thus requiring the blocks to be of bigger sizes. In the case of the Basilica, an onsite inspection of the exposed walls revealed that large-sized laterite stones were used to withstand the load of the monumental walls. Which means, replacing damaged stones of the Basilica is more difficult than replacing bricks in a similar setting because the size of the stones are much bigger. Furthermore, replacing too many damaged laterite stones would be a challenge during restoration, as the process could compromise the structural safety of the walls.

Figure 4. Closeup of the Basilica of Bom Jesus (August 2021)

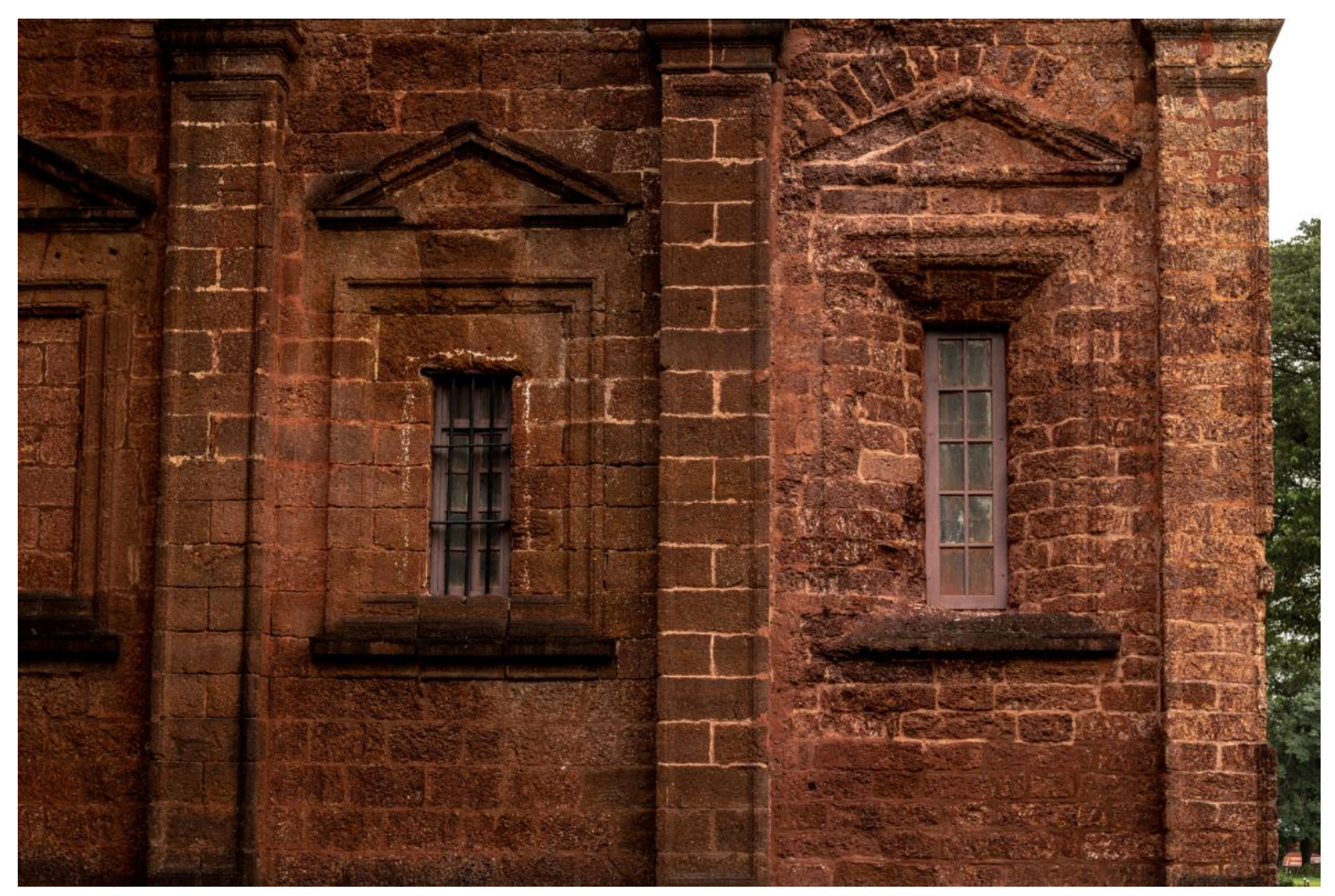

Image showing the deterioration of the laterite walls, including architectural elements like pediments over windows and pilasters. Seen here, the pediment over the right-hand side window is irreversibly damaged due to the lashing of monsoonal rains. (Author's photograph, August 2021). 
eTropic 20.2 (2021) Special Issue: Tropical Imaginaries and Climate Crisis

Das suggests that the lifespan of monuments built with Goan laterite could be best protected by using a water repellent layer over the stone (Das, 2008). However, while transparent water repellent layers such as polymer-based films might help in retaining the look of the exposed laterite stone, they are not a long-term solution for heritage structures. According to studies of the Angkor monuments mentioned earlier, "applications of water repellant and synthetic polymers are not recommended because the stability and integrity of these materials are in questions for long-term effectiveness" (Liu et al., 2020, p. 11). Further, as the surface of laterite is visibly porous with uneven texture, polymers would be ineffective in successfully sealing the stone's surface. Lastly, even if expensive polymer-based repellent could completely seal the exposed surface of the laterite, it would still be ineffective. This is because, laterite absorbs water through capillary action, which means water from the ground could still penetrate the walls and endanger the Basilica. Therefore, lime-based mortar, when done properly is better than even Portland cement, as lime-render allows the surface to breathe, helping the evaporation of the water absorbed by laterite stone through capillary action. With the addition of a lime-based render as a protective layer over the exposed laterite stones of the Basilica, the damage being witnessed now could possibly be reversed by returning the structure to the way it was. Once again, there is no better water-proofing layer than the lime-based mortar, a traditional technique practiced in Goa.

\section{Laterite and 'Mud Packs'}

Although the ASI have made efforts to retain the exposed-laterite appearance of the Basilica, its methods have not worked. As the rector notes, the "Basilica can collapse 'at any moment', [it] must be plastered soon" (TNN, 2021a). Currently, the surface of deteriorated laterite stones is temporarily consolidated using a superficial application layer called "mud pack", which was advocated by Archaeologist Nizamuddin Taher during his term in Goa (2020, para. 4). This restoration technique, alternatively known as "laterite pack" involves "filling the cavities on the surface of the [deteriorated] wall with composite mortar i.e., laterite nodules[,] lime mortar and brick-surkhi" (Tewari, 2015 , p. 268). Essentially, this is a cosmetic mortar mixture meant only to mimic the brown appearance of laterite stone. This technique of reconstruction, however, makes the patched parts stand out from the original stone, an affected difference that is very noticeable upon closer observation. In using a temporary patchwork of mud-mixture on deteriorated laterite blocks the ASI adopts a passive and superficial approach, hoping to arrest only visible signs of ageing in the Basilica.

Problematically, the current use of the laterite pack restoration does not consider how it is going to perform in the increasingly degrading climatic conditions of Goa. Taher does agree that subsequent to the application of the laterite pack, the Basilica could do with the application of a lime-based sacrificial layer (2020, para. 4), however, he 
eTropic 20.2 (2021) Special Issue: Tropical Imaginaries and Climate Crisis

puts the onus of this decision on the Church authorities, essentially absolving the ASI of its responsibility in safeguarding the monument.

\section{Rains and Indigenous Practices}

In Goa, walls of a building were additionally protected through other traditional measures. For instance, it is a common practice in Goa to cover the walls of buildings with layers of coconut fronds to keep the rainwater away during monsoons. The ferocity of monsoons in Goa is such that even today, additional efforts are needed to avoid buildings getting damaged from lashing rains. In his essay, "Before the Rains," Tony De Sa recounts the annual work undertaken to protect Goan houses before monsoons in the 1960s and 70s. He writes of how adobe walls of Goan houses were coated with lime plaster, and adds that the walls were additionally protected by,

woven palm fronds called mollam. These mollam were in great demand so if they were not available, dried palm fronds would be tied to the latticework of bamboo sticks.... Of course, as the years went by, and cement became available and labour for tying the zodd became scarce, people simply plastered the exterior walls with cement and that eliminated the need for a zodd (De Sa, 2020).

De Sa reflects on how the knowledge of traditional house-protection has been lost over time due to changes in architectural practices as well as changes in the economy. Not only has the style of houses changed, but additionally people's occupations away from their homes do not allow them the time to do such laborious work. However, even if they did have the time, these efforts would now be insufficient because rainfall has increased, and these methods would not be able to withstand the cyclones.

Unlike traditionally built Goan houses, Bom Jesus does not have any roof overhang or arcaded veranda running along the building to protect the walls from heavy rains. Further, the very monumentality of the Basilica means a large surface area of exposed walls are pounded by unforgiving rains. Furthermore, no additional measures are undertaken to protect the exposed walls during the monsoons. The ASI - whose headquarters are in Delhi, a place which does not receive the same amount and intensity of rainfall as Goa - needs to tap into traditional knowledge of conservation from local Goans if it is to sincerely hope to protect these monuments for future generations. Fr. Fernandes mentions that the personnel at the Goa ASI office have shown much concern for the deteriorating conditions of the Basilica's laterite, but they are awaiting permission from Delhi to even start the process for taking action (Fernandes, 2020, para. 6). This top-down approach of the ASI to the conservation of the Basilica signals a missed opportunity regarding existing indigenous knowledge of how to deal with monsoons in Goa. It likewise indicates the inherent coloniality of the 
eTropic 20.2 (2021) Special Issue: Tropical Imaginaries and Climate Crisis

centre versus the periphery, characteristic of all things between India and Goa. This contemporary coloniality reflects the European colonial practice when architectrestorer da Silva Castro, was sent from the Portuguese metropole to Goa - and had the render of the Basilica removed.

\section{Aesthetics and Conservation}

The former archaeologist who worked with the ASI Goa for two terms, Taher states, there is a problem in communication between the two major stakeholders of the Basilica, meaning "the owner of the property - Church Authorities - and the custodian of the property - Archaeological Survey of India" (Taher, 2020, para. 13). To make matters worse, the stakeholders address the structure differently. As Taher notes, one refers to the structure as a 'Church,' whereas the other considers it simply a 'Monument'; "[t]o one, it is of immense spiritual value and to the other it is a World Heritage property" (2020, para. 13). Given Goan Catholics are today a minority community in India, does religious bias influence the position of the ASI regarding the restoration of Bom Jesus? The monument is, above all, a marker of the Catholic heritage of Goa, and it tells an inconvenient history of the region from the perspective of the dominant right-wing Brahmanical Hindu ideology of present-day India.

It would also seem that the World Heritage classification of Bom Jesus may serve the needs of the tourism industry at the expense of the needs of the Goan Catholic community to whom the monument belongs. According to Santhi Kavuri-Bauer, there are many problems which expose contradictions in listing monuments as World Heritage. She writes,

As monuments selected as the finest examples of the diversity of human achievement come to be ordered by a standardized set of global values and touristic practices, the surrounding culture is reduced to spectacle, and handicraft production and festivals become mere historical reenactments. Local economies are forced to assimilate to a service industry and to provide labor and resources to keep the hotels, bars, restaurants, and visitor centers running (Kavuri-Bauer, 2011, p. 157).

Even though Kavuri-Bauer's remarks are in reference to Mughal monuments of India, and the Muslim community in particular, her critique is equally applicable to IndoPortuguese Catholic religious monuments of Goa - not least because both communities are religious minorities in India. Lucia Allias notes, "The use of "world" signaled the advent of environmental thought, where heritage is not made of punctual goods to be shared between nations but rather a territorial resource shared among them" (Allais, 2018, p. 28). As monuments become resources in service of the nation, 
eTropic 20.2 (2021) Special Issue: Tropical Imaginaries and Climate Crisis

the stakes and claims of locals, especially those religious monuments belonging to a minority community like the Catholics of Goa, are overlooked.

For the government and tourism corporations, the popularity of a brown-looking exposed laterite Bom Jesus holds sway. This is the famous image that the state projected to market Goa as a destination for tourism (Kandolkar, 2020a, p. 1). To the state, the inclusion of Bom Jesus as a part of World Heritage, means the monument simply serves as one more site on Goa's tourism circuit. Not surprisingly, holidaymakers from the rest of India look upon churches and congregations in Goa through a touristic gaze, as if the place and its people were part of a museum (Kandolkar, 2019, para. 4). In fact, as R. Benedito Ferrão (2021, p. 136) notes, the tropical setting and Lusophone culture of Goa "sets the former Portuguese colony as a pleasure periphery to India where, seemingly, anything goes," because Goa's economy has become overly beholden to tourism.

The inability of the two main stakeholders to find common ground is making the question of onus and responsibility for, and roles of, maintaining the church fraught. Yet in practical terms the current approach of the ASI, to treat even living monuments as rigid relics of history, is not dissimilar to that of the Church. In 2016, the former rector of the Basilica, Fr. Savio Baretto, echoing the position of the Goan Archdiocese, opposed the restoration of Bom Jesus just because "[m]ost ... Goans have been born to the sight of a red bricked [laterite] church. Having it plastered will hurt the sentiments of the people of Goa more than anything" (The Goan Network, 2016, para. 4). For the former rector, the 'sight' of the brown Basilica is critical, otherwise it is not the same building that most people of the present generation are accustomed to. However, since the incidence of rain in the Basilica in April 2020, the current rector, Fr. Patricio, has taken the opposite stand. He has appealed to both the Archdiocese and the ASI for the restoration of the Basilica's render, as he has personally witnessed rapid deterioration of the building over the past few years (2020, para. 5).

In ideological terms the ASI and the Church may have different motivations - the former freezes the appearance of the Basilica to showcase it as a "ruin," a vestige of a bygone era for tourism purposes, and the latter maintains the status quo to avoid hurting 'the sentiments of the people of Goa' - but in practical terms their approach is the same. Both approaches to the conservation of the Basilica are based on a misrecognition of the correct architectural history and enviro-heritage practices in Goa. The neglect that ensues to the building has repercussions for the future of Goan Catholics, even as Goa has experienced the heaviest rainfall in decades this year (Janwalkar, 2021). 
eTropic 20.2 (2021) Special Issue: Tropical Imaginaries and Climate Crisis

\section{Living Relics}

As common lore holds, St. Francis Xavier is believed to have protected the state from raging storms emanating from the Arabian Sea. However, tropical storms are becoming stronger and even as Goans continue to seek the saint's protection, the effects of climate change, along with increased precipitation, has endangered the very building which houses the saint's relics. The calamity of rain in the Basilica in April 2020 was met with public outrage, ensuring the Bom Jesus' safety for the time being. However, those responsible for the care of the monument will now have to do more, factoring in all the effects of climate change on the Basilica, which continues to remain without its protective lime-based render.

In the times of climate change, the ASI needs to have a transparent and scientificallyinformed dialogue with the Church and all local stakeholders, gaining their trust and participation in conserving this important symbol of Goa and its unique identity. Meanwhile, the state of Goa will have to protect the ecological context in which it is located. In the case of the Basilica, this involves the entire riverine ecosystem of River Mandovi, which goes all the way to the great Western Ghats mountain range. Recently, the state has embarked on developments in this region, which involves the cutting of 50 thousands trees in the rich bio-diverse rainforest of the Western Ghats, itself a UNESCO listed World Heritage Site (Halarnkar, 2020, para. 3). Essentially, conservation of built heritage and ecological heritage should not be seen as being different from one another. Merely focussing on protecting heritage buildings as relics and ignoring the environment would also spell disaster, despite taking all precautions to conserve the physical form and aesthetics of monuments, including the Basilica.

The Basilica is a part of a living cultural heritage, which means that the state also has to ensure the local community that continues to use the church is given adequate protection. After all, Goans are as much part of the intangible heritage of the land, just as the Indo-Portuguese buildings are evidence of Goa's history. It has to be understood that living monuments are not a standalone object of history but are entangled within the cultural and ecological contexts in which they are situated. In the face of climate change and its effect on the tropical Global South, I would like to extend Achille Mbembe's idea of planetary entanglement (2017). With culturally unique places like Goa, the built and ecological heritage have to be imagined together with its people, creating a system of regional entanglement. Thinking regionally would in turn help in dealing with the challenges of climate change on a planetary level. Harming any one of the elements - monument, ecology, local people - would mean inviting disasters at a global level, as has happened with climate change. 
eTropic 20.2 (2021) Special Issue: Tropical Imaginaries and Climate Crisis

\section{References}

Allais, L. (2018). Designs of Destruction: The Making of Monuments in the Twentieth Century. The University of Chicago Press. https://doi.org/10.7208/chicago/9780226522616.001.0001

Azzali, S., Law. L., \& Lundberg, A. (2020). Sustainable Tropical Urbanism: Insights from Cities of the Monsoonal Asia-Pacific. eTropic: electronic journal of studies in the tropics 19 (2), 1-24. https://doi.org/10.25120/etropic.19.2.2020.3777

Das, S. (2008). Decay Diagnosis of Goan Laterite Stone Monuments. In A. N. Türkeri (Ed). Durability of building materials and components 11. İstanbul Teknik Üniversitesi

de Albuquerque, V. A. C. B. (1890). Casa Professa e Igreja do Bom Jesus: Onde se Venera o Corpo do Glorioso Apostolo das Indias S. Francisco Xavier: Memoria HistoricoDescriptiva, Illustrada com Estampas. Imprensa Nacional.

D'Cruz, D. (2019, March 12). Goencho Saib-Goa's greatest unifier. OHeraldo. https://www.heraldgoa.in/Cafe/Goencho-SaibGoas-greatest-unifier/154280

De Sa, T. (2020, April 2). Before the Rains. Joao-Roque Literary Journal. https://www.joaoroqueliteraryjournal.com/nonfiction-1/2020/1/15/before-the-rainsarrived

dos Santos, J. R. (2016). Reinstalling the Old City of Goa as an Eternal Light of Portuguese Spirituality: The Plan for the Reintegration of Old Goa at the End of the Colonial Period. Architectural Histories, 4(1), 1-21. https://doi.org/10.5334/ah.58

dos Santos, J. R. (2017). On the Trail of Baltazar Castro, a Portuguese Restorer in India. Papers from the International Scientific Thematic Conference EAHN 2015 Belgrade: Entangled Histories, Multiple Geographies, 244-253.

Evan, A. T., Kossin, J. P., 'Eddy' Chung, C., \& Ramanathan, V. (2011). Arabian Sea tropical cyclones intensified by emissions of black carbon and other aerosols. Nature, 479(7371), 94-97. https://doi.org/10.1038/nature10552

Fernandes, P. (2020, November 1). World heritage structure $\&$ an archaeological marvel, but in danger of deteriorating. OHeraldo. https://www.heraldgoa.in/Review/Worldheritage-structure-an-archaeological-marvel-but-in-danger-of-deteriorating/169582

Ferrão, R. B. (2021). Running Naked and Unmasked in Goa: Pleasure in the Pandemic. eTropic: Electronic Journal of Studies in the Tropics, 20(1), 134-156. https://doi.org/10.25120/etropic.20.1.2021.3789

Fonseca, J. N. da. (1878). An Historical and Archaeological Sketch of the City of Goa. Thacker \& Co, Limited.

Ghosh, A. (2021, May 23). Cyclone Tauktae knocked over a great tree of life in my Goa home-We must build better resilience for climate change. The Times of India (S. M. Das, Interviewer) [Interview]. https://timesofindia.indiatimes.com/cyclone-tauktaeknocked-over-a-great-tree-of-life-in-my-goa-home-we-must-build-better-resiliencefor-climate-change/articleshow/82838593.cms

Goa State Biodiversity Board. (2019). State Action Plan on Climate Change for the State of Goa: For Period of 2020-2030. https://gsbb.goa.gov.in/wpcontent/uploads/2020/12/Draft-Goa\%20SAPCC-for-public-inputs.pdf

Gupta, P. (2014). The Relic State: St Francis Xavier and the Politics of Ritual in Portuguese India. Manchester University Press : distributed in the United States exclusively by Palgrave Macmillan. https://doi.org/10.7228/manchester/9780719090615.001.0001

Halarnkar, S. (2020, March 12). India accelerates its age of ecological annihilation. Scroll.in. https://scroll.in/article/979892/india-accelerates-its-age-of-ecological-annihilation

Janwalkar, M. (2021, July 24). Incessant rain triggers Goa's worst floods in decades; property worth crores damaged. The Indian Express. 
eTropic 20.2 (2021) Special Issue: Tropical Imaginaries and Climate Crisis

https://indianexpress.com/article/cities/goa/goa-cm-pramod-sawant-visits-floodaffected-areas-as-rescue-work-progresses-7418628/

Kandolkar, V. (2019). Reclaiming Goan Identity Through the Feast of Saint Francis Xavier. Economic and Political Weekly, 54(48). https://www.epw.in/engage/article/reclaiminggoan-identity-through-feast-saint

Kandolkar, V. (2020a). Architecture and the Structure of Goan Identity in the "Postcolonial" Period. Manipal Academy of Higher Education.

Kandolkar, V. (2020b). Restoring Basilica of Bom Jesus, and the Role of Archaeological Survey of India. Economic and Political Weekly, 55(36). https://www.epw.in/engage/article/restoring-basilica-bom-jesus-and-archaeologicalsurvey-india

Kasthurba, A. K., Santhanam, M., \& Mathews, M. S. (2006). Weathering Forms and Properties of Laterite Building Stones Used in Historic Monuments of Western India. In P. B. Lourenço, P. Roca, C. Modena, \& S. Agrawal (Eds.), Structural analysis of historical constructions 2. 2. Macmillan.

Kavuri-Bauer, S. (2011). Monumental matters: The power, subjectivity, and space of India's Mughal architecture. Duke University Press. https://doi.org/10.1215/9780822393764

Liu, X., Koestler, R. J., Warscheid, T., Katayama, Y., \& Gu, J.-D. (2020). Microbial deterioration and sustainable conservation of stone monuments and buildings. Nature Sustainability, 3(12), 991-1004. https://doi.org/10.1038/s41893-020-00602-5

Lundberg, A. (2020). Balinese dancer wearing a gas mask: Climate change and the tropical imaginary. Scottish Geographical Journal, 136(1-4), 91-100. https://doi.org/10.1080/14702541.2020.1858589

Mbembe, A. (2017, August 4). Time on the Move. https://www.ici-berlin.org/events/achillembembe/

Murakami, H., Vecchi, G. A., \& Underwood, S. (2017). Increasing frequency of extremely severe cyclonic storms over the Arabian Sea. Nature Climate Change, 7(12), 885889. https://doi.org/10.1038/s41558-017-0008-6

Nogueira, R., Ferreira Pinto, A. P., \& Gomes, A. (2018). Design and behavior of traditional lime-based plasters and renders. Review and critical appraisal of strengths and weaknesses. Cement and Concrete Composites, 89, 192-204. https://doi.org/10.1016/j.cemconcomp.2018.03.005

NT Desk. (2020, April 23). Urgent efforts are needed to ensure the Basilica is protected for future generation: Fr. Patricio. The Navhind Times. https://www.navhindtimes.in/urgent-efforts-needed-to-ensure-basilica-is-protectedfor-future-generations-fr-patricio/

O'Neill, S. J., \& Smith, N. (2014). Climate change and visual imagery. WIREs Climate Change, 5(1), 73-87. https://doi.org/10.1002/wcc.249

Patil, S. M., \& Kasthurba, A. K. (2021). Weathering of stone monuments: Damage assessment of basalt and laterite. Materials Today: Proceedings, 43, 1647-1658. https://doi.org/10.1016/j.matpr.2020.10.022

Prathipati, V. K., C. V., N., \& Konatham, P. (2019). Inconsistency in the frequency of rainfall events in the Indian summer monsoon season. International Journal of Climatology, 39(13), 4907-4923. https://doi.org/10.1002/joc.6113

Salazar, O. (1956, April). Goa and the Indian Union-The Portuguese View. Foreign Affairs, 34(3), 418-431. https://doi.org/10.2307/20031174

Shetty, D. (2021, July 13). In Goa, The Water Runs Black. Pulitzer Center. https://pulitzercenter.org/stories/goa-water-runs-black

Smith, B. J., Gomez-Heras, M., \& McCabe, S. (2008). Understanding the decay of stonebuilt cultural heritage. Progress in Physical Geography: Earth and Environment, 32(4), 439-461. https://doi.org/10.1177/0309133308098119 
eTropic 20.2 (2021) Special Issue: Tropical Imaginaries and Climate Crisis

Taher, N. (2020, May 10). Preserving a World Heritage Monument. Herald. https://www.heraldgoa.in/Review/Preserving-a-World-Heritage-Monument/160394

Team Herald. (2020, April 24). ASI has neglected conservation of the Basilica at Old Goa: Rector. Herald. https://www.heraldgoa.in/Goa/ASI-has-neglected-conservation-ofthe-Basilica-at-Old-Goa-Rector/159763

Tewari, R. (Ed.). (2015). Indian Archaeology 2008-2009: A Review. In Archaeological Survey of India. Archaeological Survey of India.

The Goan Network. (2016, October 2). Plastering Basilica; Church says Oh God, Please Don't. The Goan. http://englishnews.thegoan.net/story.php?id=11003

TNN. (2014, October 10). Goa "very vulnerable to climate-change impacts": Pachauri. Times of India. https://timesofindia.indiatimes.com/city/goa/Goa-very-vulnerable-to-climatechange-impacts-Pachauri/articleshow/44872403.cms

TNN. (2020, July 20). Goa: Portuguese-era building collapses in Panaji, three rescued from structure. The Times of India.

https://timesofindia.indiatimes.com/city/goa/portuguese-era-building-collapses-inpanaji-three-rescued-from-structure/articleshow/77057129.cms

TNN. (2021a, January 25). Basilica can collapse 'at any moment', must be plastered soon: Rector. The Times of India. https://timesofindia.indiatimes.com/city/goa/basilica-cancollapse-at-any-moment-must-be-plastered-soon-rector/articleshow/80439361.cms

TNN. (2021b, June 5). Heritage lovers raise flooding alert, call for expediting Basilica work on priority. Times of India. https://timesofindia.indiatimes.com/city/goa/heritagelovers-raise-flooding-alert-call-for-expediting-basilica-work-onpriority/articleshow/82417744.cms

UNESCO World Heritage Committee (Tenth Session). (1986). Convention Concerning the Protection of the World Cultural and Natural Heritage. United Nations Educational Scientific and Cultural Organization.

Vallangi, N. (2021, May 27). Rapid heating of Indian Ocean worsening cyclones, say scientists. The Guardian. https://www.theguardian.com/environment/2021/may/27/rapid-heating-of-indianocean-worsening-cyclones-say-scientists

Velho, F. (2021, April 19). Local Identity, Global Heritage: Conserving the Basilica of Bom Jesus.

Wang, B., Xu, S., \& Wu, L. (2012). Intensified Arabian Sea tropical storms. Nature, 489(7416), E1-E2. https://doi.org/10.1038/nature11470

Yeung, J., \& Mitra, E. (2021, May 18). India lashed by strongest cyclone to ever hit west coast as it reels from Covid disaster. CNN. https://edition.cnn.com/2021/05/18/india/india-cyclone-tauktae-covid-monsoon-intl$\underline{\mathrm{hnk} / \mathrm{index} \cdot \mathrm{html}}$ 
eTropic 20.2 (2021) Special Issue: Tropical Imaginaries and Climate Crisis

\section{Acknowledgements}

My gratitude to R. Benedito Ferrão and Suneeta Peres da Costa for their insightful feedback and support during the process of writing this article. I am grateful to Fr. Patricio Fernandes, the current rector of the Basilica of Bom Jesus, who familiarised me with the problems facing the conservation of the monument. Finally, many thanks to architect Lester Silveira who helped with the photographs of Bom Jesus appearing here.

Vishvesh Prabhakar Kandolkar, $\mathrm{PhD}$, is an Associate Professor of Architecture at Goa College of Architecture (Goa University) and the Programme Coordinator of the Masters of Architecture in Urban Design programme at the college. His research on Goa's architectural history focuses on early modern church design, as well as the evolution of Indo-Portuguese aesthetics. His writing has appeared, or is forthcoming, in Economic and Political Weekly, Journal of Human Values, and Journal of Hindu Studies. Based on his research about the Bom Jesus Basilica, Kandolkar's art installation, This is Not the Basilica!, will be exhibited at Sunaparanta Goa Centre for the Arts from 8th September to 20th November 2021. 